\title{
First record of Pallenopsis fluminensis (Krøyer, 1844) (Pycnogonida: Pallenopsidae) for the coast of the state of Paraíba (northeastern Brazil)
}

\author{
Rudá Amorim Lucena ${ }^{1}$, Silvio Felipe B. Lima ${ }^{2,3} \&$ Martin Lindsey Christoffersen $^{1}$
}

(1) Universidade Federal da Paraíba - Campus I, Departamento de Sistemática e Ecologia, Programa de Pós-Graduação em Ciências Biológicas, Cidade Universitária, João Pessoa 58051-900, Paraíba, Brazil. Email: rudalucena15@gmail.com, mlchrist@dse.ufpb.br

(2) Universidade Federal de Campina Grande, Centro de Formação de Professores, Unidade Acadêmica de Ciências Exatas e da Natureza, Rua Sérgio Moreira de Figueiredo, Casas Populares, Cajazeiras 58900000, Paraíba, Brazil. E-mail: sfblima@gmail.com

(3) Universidade Federal da Paraíba - Campus II, Departamento de Ciências Biológicas, Programa de PósGraduação em Biodiversidade, Cidade Universitária, Areia 58397-000, Paraíba, Brazil.

Lucena R.A., Lima S.F.B. \& Christoffersen M.L. (2017) First record of Pallenopsis fluminensis (Krøyer, 1844) (Pycnogonida: Pallenopsidae) for the coast of the state of Paraíba (northeastern Brazil). Pesquisa e Ensino em Ciências Exatas e da Natureza, 1(1): 19-27.

Primeiro registro de Pallenopsis fluminensis (Krøyer, 1844) (Pycnogonida: Pallenopsidae) para a costa do estado da Paraíba (nordeste do Brasil)

Resumo: Uma espécie de picnogonídeo classificada na família Pallenopsidae Fry, 1978 e no gênero Pallenopsis Wilson, 1881 é registrada neste estudo para a costa do estado da Paraíba (nordeste do Brasil), com base na identificação de três espécimes fêmeas coletadas na zona infralitoral em profundidades de 12 a 34 metros. Pallenopsis fluminensis (Krøyer, 1844) é a quarta espécie de Pycnogonida registrada para a região. Até então, apenas Anoplodactylus batangensis (Helfer, 1938), A. eroticus Stock, 1968 e A. mirim Lucena, Araújo \& Christoffersen, 2015 haviam sido registradas para a costa da Paraíba. Pallenopsis fluminensis é diagnosticada pelo tronco com setas pequenas na borda distal de cada segmento; probóscide com setas terminais; processos laterais com pequenas setas dorsais; palpos sem setas e reduzidos a um pequeno tubérculo; quela com muitas setas, palma 1.5 vezes mais longa que larga; ovígeros com oito artículos nas fêmeas, sendo os artículos 5 e 6 subiguais, e o 8 pouco menor que o 7; e a tíbia 1 sem uma cobertura densa de setas. Até o momento, $P$. fluminensis é a única congênere proveniente da costa Atlântica da América do Sul sem uma densa cobertura de setas sobre a tíbia 1.

Palavras chave: Arthropoda, Chelicerata, Pantopoda, Atlântico oeste, região tropical, zona costeira.

Abstract: A pycnogonid species classified in the family Pallenopsidae Fry, 1978 and the genus Pallenopsis Wilson, 1881 is recorded in this study for the coast of the state of Paraíba in northeastern Brazil based on the identification of three female specimens collected from the infralittoral zone at depths of 12 to 34 meters. Pallenopsis fluminensis (Krøyer, 1844) is the fourth species of Pycnogonida recorded for the region. To date, only Anoplodactylus batangensis (Helfer, 1938), A. eroticus Stock, 1968 and A. mirim Lucena, Araújo \& Christoffersen, 2015 have been recorded for the coast of the state of Paraíba. Pallenopsis fluminensis is diagnosed by a trunk with small setae on the distal border of each segment; proboscis with terminal setae; lateral processes with small setae; palps without setae and reduced to a small knob; chela with many setae, palm 1.5 times longer than wide; ovigers with eight articles on females, articles 5 and 6 subequal and article 8 not much smaller than 7; and tibia 1 without dense cover of the setae. To date, $P$. fluminensis is the only congener from the Atlantic coast of South America without a dense cover of setae on tibia 1.

Key words: Arthropoda, Chelicerata, Pantopoda, Western Atlantic, tropical region, coastal zone. 


\section{Introduction}

Pycnogonids are benthic or pelagic marine arthropods, with approximately 1340 recent species considered valid (Bamber 2008; Appeltans et al. 2012), which are globally distributed from tropical to polar seas (Arnaud \& Bamber 1987). Pycnogonid communities inhabit a variety of intertidal to deep sea environments and are usually associated with diverse biogenic microhabitats (Arnaud \& Bamber 1987; Stock 1992). These animals occur among algae or even on/between other metazoans, such as poriferans, cnidarians, mollusks, echinoderms and sea squirts (Correa 1987; Arango 2003), mainly hydrozoans (Marcus 1940a; King 1974; Varoli 1996). Species of the group are herbivorous, detritivorous, commensal, carnivorous or even parasitic on a number of invertebrates (Bamber \& Davies 1982; Arnaud \& Bamber 1987; Dunlop \& Arango 2005), particularly anthozoans (Staples 2002).

Little information is found regarding pycnogonid fauna on the coast of Brazil, where the group has been scarcely and sporadically addressed in the literature (see Lucena 2016). However, there have been recent efforts regarding the study of the biodiversity of the group, which has increased knowledge on species richness in northeastern Brazil (Lucena et al. 2015; Lucena 2016; Lucena \& Christoffersen 2016).

The family Pallenopsidae Fry, 1978 includes approximately 82 recent species of pycnogonids classified in the genera Bathypallenopsis Stock, 1975 and Pallenopsis Wilson, 1881 (Bamber 2009). Pallenopsis is the more diversified group of the family, with about 61 recent species worldwide (Bamber 2010), distributed predominantly in shallow tropical and subtropical marine ecoregions mainly on the Atlantic coast of South America (Stock 1974; Bamber 2007). Species of Pallenopsis differ from Bathypallenopsis in having fingers smaller than the palm, positioned at a straight angle in relation to the palm as well as a short abdomen and proboscis. Species of Bathypallenopsis have fingers larger than the palm as well as an elongated abdomen and proboscis (Child 1998).

To the best of our knowledge, only three pycnogonid species are recorded for the coast of Paraíba: Anoplodactylus batangensis (Helfer, 1938), A. eroticus Stock, 1968 and A. mirim Lucena, de Araújo \& Christoffersen, 2015. However, the pycogonid biodiversity of coastal ecosystems in northeastern Brazil, such as those found on the coast of Paraíba, undoubtedly remain underestimated.

Little information is found regarding pycnogonid fauna in northeastern Brazil (Lucena et al. 2015; Lucena 2016; Lucena \& Christoffersen 2016). The purpose of this paper is to provide additional information on pycnogonid richness along the coast of Paraíba based on the record of female specimens of Pallenopsis fluminensis (Krøyer, 1844). This is the fourth pycnogonid species recorded for the state.

\section{Material and Methods}

\section{Study site}

The state of Paraíba in northeastern Brazil has approximately $138 \mathrm{~km}$ of coastline (De Assis et al. 2012) and an important diversity of coastal ecosystems (see Melo et al. 2006; Araújo et al. 2008; De Assis et al. 2012; Lima et al. 2014, 2017; Medeiros et al. 2016). The coast of Paraíba begins at the mouth of the Guajú River on the border with the state of Rio Grande do Norte to the north and ends at the mouth of the Goiana River on the border with the state of Pernambuco to the south (Feliciano \& Melo 2003) (Figure 1).

\section{Data collection and analysis}

All specimens studied were collected by the vessel "Pesquisador IV" using a dredge from the continental shelf off the state of Paraíba at depths ranging from 10 to $35 \mathrm{~m}$ during the development of the "Algas-PB/UFPB Project" (January and June 1981). Figure 1 shows the sampling sites of this project as well as the locations from which the pycnogonid specimens 
were collected. Information on the collection methods for the benthos of this project is described by Melo \& Veloso (2005).

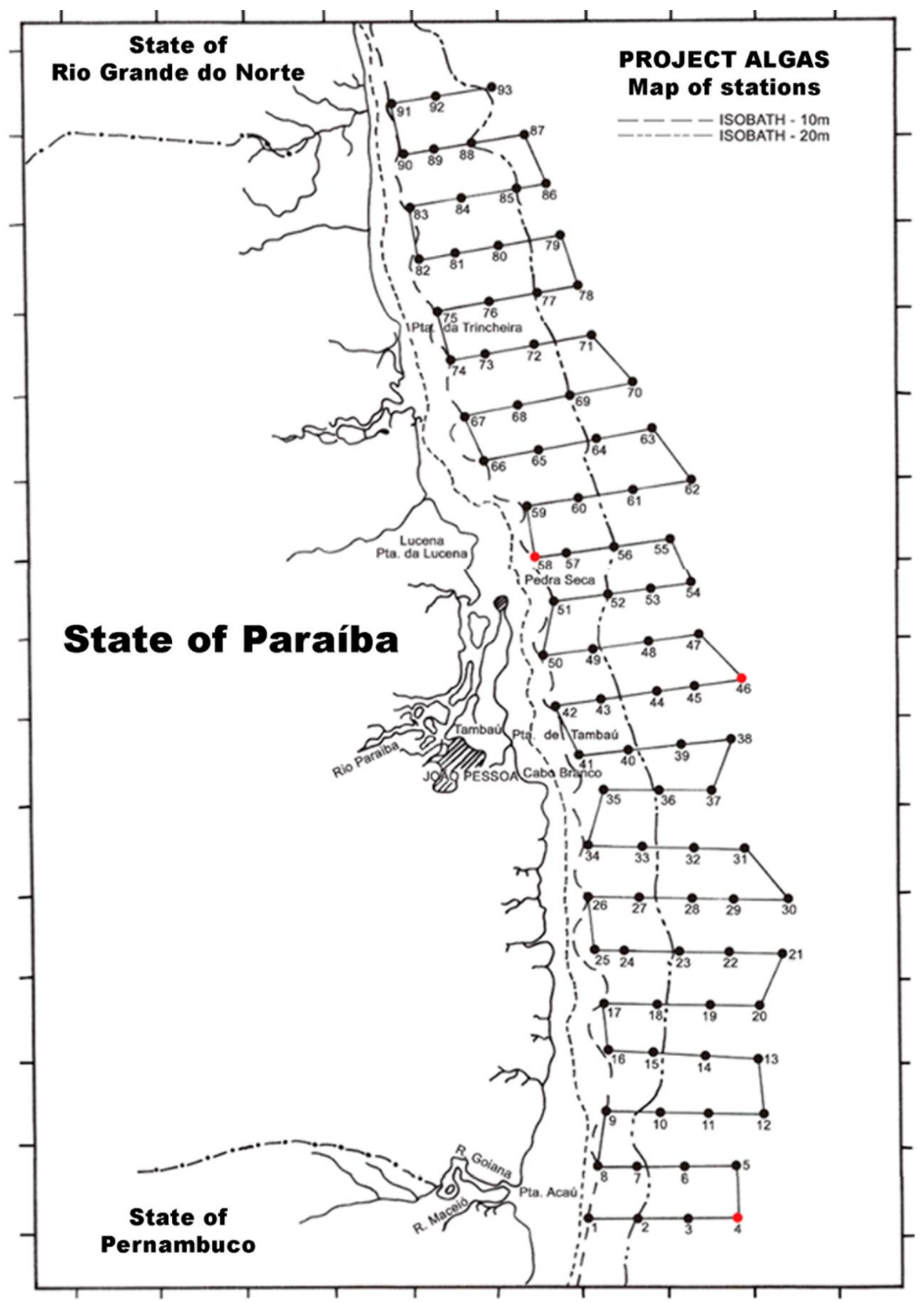

Figure 1. Map of the sampling sites of Algas Project. Circles in red - sites where the pycnogonids were collected (modified from Melo \& Veloso 2005).

Identification of the specimens was performed under a stereomicroscope based on comparisons with pycnogonids studied mainly by Marcus (1940a), Stock (1975) and Child (1998). 
When necessary, the ovigers and third legs of specimens were detached and mounted as permanent slides in Hoyer's medium as an aid for identification. Drawings were made using a stereomicroscope and an optical microscope, both with a camera lucida. The drawings were scanned and edited using computer software.

All specimens examined are deposited in the Pycnogonida collection of the "Laboratório de Invertebrados Paulo Young, Departamento de Sistemática e Ecologia, Universidade Federal da Paraíba (UFPB.PYC)", João Pessoa, Paraíba, Brazil. In the material examined, the number inside square brackets indicates the number of specimens in each sample.

\title{
Results
}

\author{
Pycnogonida Latreille, 1810 \\ Pantopoda Gerstaecker, 1863 \\ Nymphonoidea Pocock, 1904 \\ Pallenopsidae Fry, 1978 \\ Pallenopsis Wilson, 1881
}

Type species: Pallenopsis fluminensis (Kroyer, 1884), subsequent designation by Stock (1974).

Diagnosis: Cephalon with ocular tubercle in anterior region, dorsally to proboscis insertion. Proboscis cylindrical with dilatation. Chelifores with two to three articles; thin scape. Chela small, fingers of same length as palm, may be positioned perpendicularly, without teeth, but sometimes with crenulated surface, distal region with many crenulations. Palp vestigial, formed by small knob. Ovigers with eight to 10 articles on females. Strigils with setae, without spines or terminal claw. Legs typical, cement gland opening in ventral narrow tube. Propodus with auxiliary claws (Child 1998: 50).

\section{Pallenopsis fluminensis (Krøyer, 1844) \\ (Figure 2A-E)}

Phoxichilidium fluminense Krøyer 1844: 104, 124, pl. I fig. 1a-f.

Pallenopsis fluminensis - Marcus 1940a: 24-27, fig. 1a-b; Marcus 1940b: 182, figs 1-6.

Pallenopsis (Pallenopsis) fluminensis Stock 1974: 1020-1021, fig. 25.

Type material: Unknown.

Type locality: Rio de Janeiro (Krøyer 1844).

Material examined: [1 ${ }^{\circ}$ ] UFPB.PYC-005, station 4, $07^{\circ} 34^{\prime} \mathrm{S}, 34^{\circ} 36^{\top} \mathrm{W}, 33 \mathrm{~m}, 22 . \mathrm{i} .1981$; [1 ${ }^{\circ}$ ] UFPB.PYC-023, station 46, $07^{\circ} 04^{\prime} \mathrm{S}, 34^{\circ} 36^{\prime} \mathrm{W}, 34 \mathrm{~m}$, 17.ii.1981; [1 ${ }^{\circ}$ ] UFPB.PYC-024, station 58, $06^{\circ} 55^{\prime} \mathrm{S}, 34^{\circ} 47^{\prime} \mathrm{W}, 12 \mathrm{~m}$, 04.ii.1981. Brazil, northeastern Brazil, continental shelf off the state of Paraíba.

Diagnosis: Trunk with small setae on distal border of each segment. Proboscis tubular, with terminal setae. Lateral processes with small setae. Palm of chela with many setae, more concentrated in terminal region. Small fingers. Palps without setae and reduced to small knob; chela with many setae, palm 1.5 times longer than wide; ovigers with eight articles on females, articles 5 and 6 subequal and article 8 not much smaller than 7. Tibia 1 without dense cover of setae. Main claw 1/2 length of propodus. Auxiliaries 4/5 length of main claw.

Description: Trunk elongated, approximately $1 \mathrm{~cm}$, with small setae on border of each segment. Proboscis tubular, with terminal setae. Lateral processes separated by own diameter, with small 
terminal setae. Ocular tubercle smaller than abdomen, conical, located above insertion of chelifores. Medium eyes. Abdomen with dorsal setae, curved backwards (Figure 2A-B).
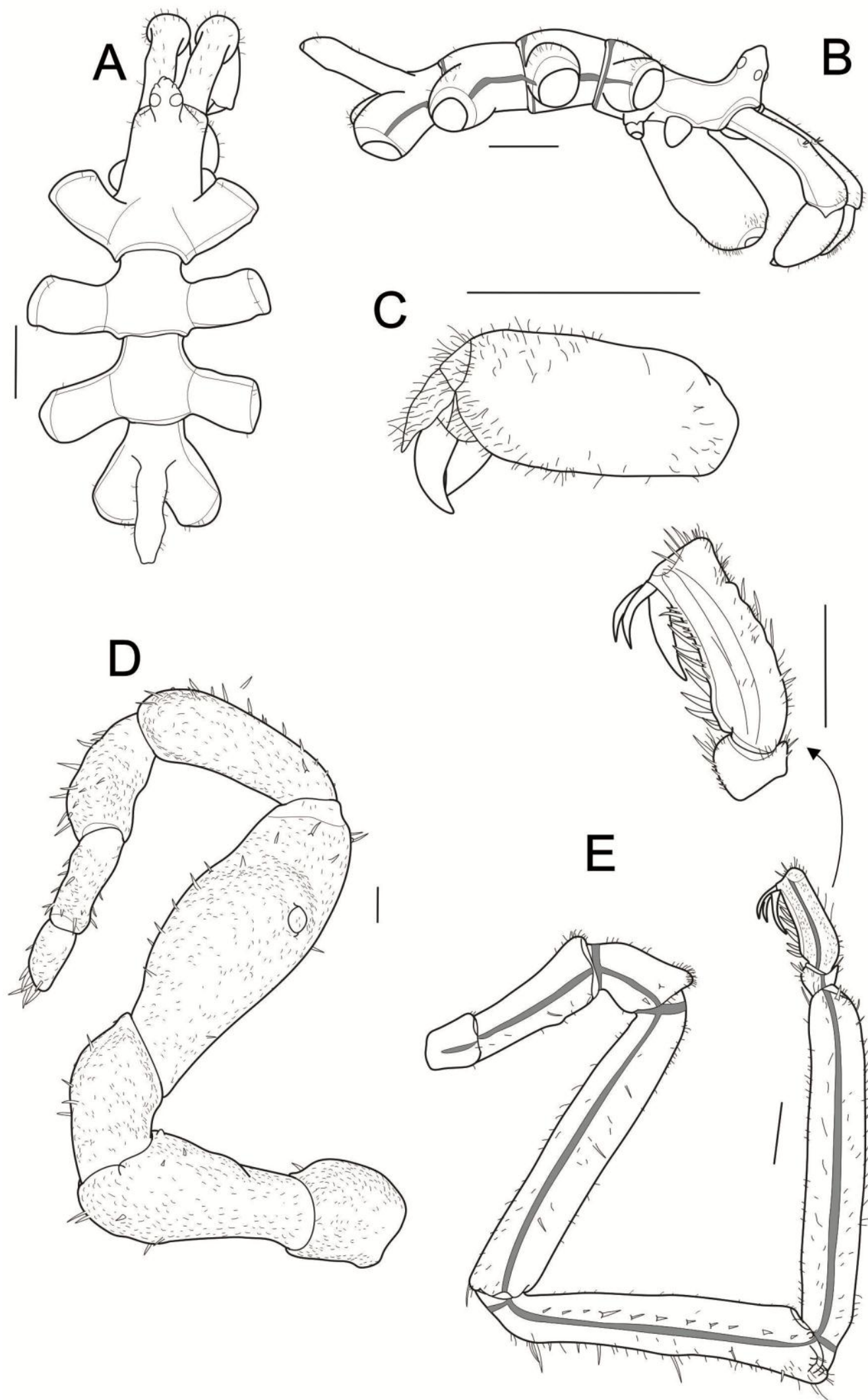

Figure 2. Pallenopsis fluminensis (UFPB.PYC-005 ㅇ): A. Habitus - dorsal; B. Habitus - lateral; C. Chela; D. Oviger; E. Third leg. Scale bars: A-C, E. $1 \mathrm{~mm}$; D. $0.1 \mathrm{~mm}$. 
Chelifore scapus one articulated, with sparse small setae and larger dorsum-medial setae (Figure 2C). Palm of chela with small setae, located in terminal region. Small fingers. Palp reduced to small oval knob, without setae. Ovigers eight articulated, all with small tubercles on cuticle (Figure 2D); article 4 longest, with lateral swelling and medium pore. Article 1 with one seta; 2 and 3 with few setae, increasing in number gradually from article 4; article 8 with terminal setae.

Legs very long (Figure 2E). Coxa 1 with few setae; coxa 2 approximately same length as coxa 1 and 3 combined, with sparse dorsal setae, small ventral setae concentrated near distal border; coxa 3 with small ventral spur covered by small setae. Femur long, with terminal setae. Tibia 1 with two long dorsal setae near proximal border, with medium, distal long setae, two latero-distal small tubercles and dorsal tubercle, with row of 11 lateral setae on each side. Tibia 2 longer than femur, with many setae concentrated on distal border. Tarsum rectangular, with many setae. Propodus with row of nine spines on sole, setae concentrated in dorsal and terminal region. Main claw 1/2 length of propodus. Auxiliaries 4/5 length of main claw.

Bathymetric range: 0 to $49 \mathrm{~m}$ (Stock 1992).

Geographic distribution: northeastern Brazil - Paraíba (present study) and Pernambuco (Stock 1974), southeastern Brazil - Rio de Janeiro (Krøyer 1844) and São Paulo (Marcus 1940a); Argentina (Hedgpeth 1943) (Figure 3).

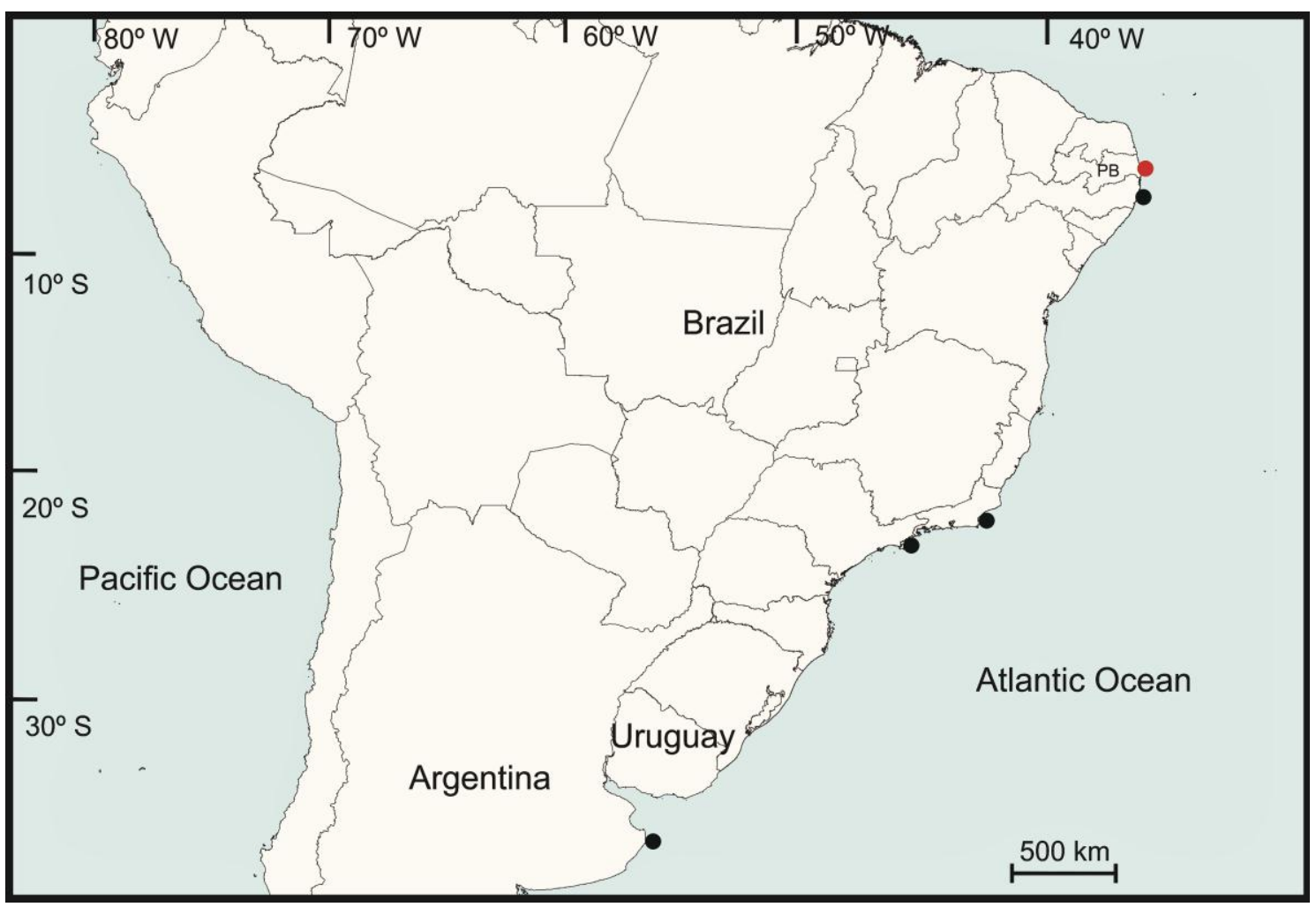

Figure 3. Geographic distribution of Pallenopsis fluminensis on the Atlantic coast of South America (black circles indicate where the species was previously collected; red circle indicates record of present study for coast of Paraíba between depths of 12 and 34 meters).

Remarks: This species was recognized as the only congener on the Atlantic coast of South America without a dense cover of setae on tibia 1 (Stock 1974). The characters of the specimens examined herein and those studied by Marcus (1940a,b) and Stock (1974) fit the concept of Pallenopsis fluminensis with regard to the palps without setae and reduced to a small knob, 
chela with many setae, palm 1.5 times longer than wide, ovigers with eight articles on females, articles 5 and 6 sub-equal and article 8 not much smaller than 7 .

\section{Discussion}

Specimens of Pallenopsis fluminensis have been collected on only a few occasions along the Atlantic coast of South America since its original description. The geographic distribution of this species is practically restricted to the Brazilian coast, except for the occurrence one record for the mouth of Rio de la Plata in Argentine waters (Hedgpeth 1943). Krøyer (1844) described this species for the state of Rio de Janeiro, but with no further details on its distribution. Marcus (1940a,b) recognized this species from the beaches of Itanhaém and Peruíbe in the state of São Paulo. Stock (1975) was the first to record this species for northeastern Brazil in the state of Pernambuco. Stock (1992) established a second record for the coast of the state of Rio de Janeiro from a depth of $49 \mathrm{~m}$.

This study is one of the few publications to address specimens of Pallenopsis fluminensis and constitutes the first record of the species for the coast of Paraíba as well as the northernmost record of all specimens described thus far. Therefore, knowledge regarding pycnogonid fauna in this region is increased to four species. Pallenopsis fluminensis is herein represented by three female specimens collected on the continental shelf off the state of Paraíba between depths of 12 and 34 meters. However, it is likely that this species has a wider bathymetric distribution in the region.

Pallenopsis fluminensis and other pycnogonid species have been studied sporadically along the Atlantic coast of South America over the years (see Marcus 1940a; Stock 1966; Child 1979; Tiago \& Migotto 1999; Lucena 2016) due primarily to the absence of zoologists who work continuously with the group, which is directly reflected by the scant samples in the region. Consequently, biological and ecological aspects of Pycnogonida are underestimated, particularly along the coast of Brazil.

Like the known distribution of Pallenopsis fluminensis, there are wide gaps in the distribution of other species of the group (Marcus 1940a; Stock 1992). Such gaps in the geographical distribution of pycnogonid species along the Atlantic coast of South America is a clear evidence of the limited knowledge on the group in the face of the considerable diversity of marine ecosystems in the region. Some studies have drawn attention to the scarcity and even lack of records of some benthic invertebrates along the northeastern coast of Brazil (Amaral \& Jablonski 2005), such as of Pycnogonida. Thus, the richness of pycnogonids and other invertebrates for the country is under-reported, even after the completion of important Brazilian programs such as the Live Resources of the Exclusive Economic Zone (REVIZEE) program (Amaral \& Jablonski 2005; Marques \& Lamas 2006; Senna et al. 2013).

\section{Acknowledgments}

The authors are grateful to the anonymous referees for their critical review, corrections and suggestions regarding the paper. The first and third authors also acknowledge a Ph.D. scholarship and productivity grant from the Brazilian fostering agencies "Coordenação de Aperfeiçoamento de Pessoal de Nível Superior (CAPES) and Conselho Nacional de Desenvolvimento Científico e Tecnológico (CNPq)" [Proc. N. 302388/2014-1], respectively.

\section{References}

Amaral A.C.Z. \& Jablonski S. (2005) Conservação da biodiversidade marinha e costeira no Brasil. Megadiversidade, 1(1): 43-51.

Appeltans W., Ahyong S.T., Anderson G., Angel M.V., Artois T., Bailly N., Bamber R., Barber A., Bartsch I., Berta A. et al. (2012) The Magnitude of Global Marine Species Diversity. Current Biology, 22: 2189-2202. 
Arango C.P. (2003) Sea spiders (Pycnogonida, Arthropoda) from the Great Barrier Reef, Australia: new species, new records and ecological annotations. Journal of Natural History, 37: 2723-2772. doi: 10.1080/00222930210158771

Araújo P.G., Miranda G.E.C. \& Kanagawa A.I. (2008) Repartição espacial da comunidade macrobêntica dos recifes da APA da Barra do Rio Mamanguape, Paraíba, Brasil. Revista Nordestina de Biologia, 19(1): 29-50.

Arnaud F. \& Bamber R.N. (1987) The Biology of Pycnogonida. Advances in Marine Biology, 24: $1-96$.

Bamber R.N. (2007) A holistic re-interpretation of the phylogeny of the Pycnogonida Latreille, 1810 (Arthropoda). Zootaxa, 1668: 295-312.

Bamber R.N. (2008) Pycnogonida. In: Bamber R.N., El Nagar A. \& Arango C. (Eds) (2016). Pycnobase: World Pycnogonida Database. Available from: http://www.marinespecies.org/pycn obase/aphia.php?p=taxdetails\&id=1302 (Accessed on 14.02.2017).

Bamber R.N. (2009) Pallenopsidae Fry, 1978. In: Bamber R.N., El Nagar A. \& Arango C. (Eds) (2016). Pycnobase: World Pycnogonida Database. Available from: http://www.marinespecies.or $\mathrm{g} /$ aphia.php? $\mathrm{p}=$ taxdetails\&id=236317 (Accessed on 10.02.2017).

Bamber R.N. (2010) Pallenopsis Wilson, 1881. In: Bamber R.N., El Nagar A. \& Arango C. (Eds) (2016). Pycnobase: World Pycnogonida Database. Available from: http://www.marinespecies.o rg/aphia.php? $\mathrm{p}=$ taxdetails\&id=134593 (Accessed on 07.02.2017).

Bamber R.N. \& Davies M.H. (1982) Feeding of Achelia echinata Hodge (Pycnogonida) on Marine Algae. Journal of Experimental Marine Biology and Ecology, 60: 181-187.

Child C.A. (1979) Shallow-Water Pycnogonida of the Isthmus of Panama and the Coasts of Middle America. Smithsonian Institution Press, 293: 1-100.

Child C.A. (1998) The Marine Fauna of New Zealand: Pycnogonida (Sea Spiders). Wellington: National Institute of Water and Atmospheric Research. $71 \mathrm{p}$.

Correa D.D. (1987) Pantopoda. Manual de Técnicas para a Preparação de Coleções Zoológicas. Campinas: Sociedade Brasileira de Zoologia. 5 p.

De Assis J.E., Samiguel C.A., Brito R.J., Christoffersen M.L. \& Santos A.S. (2012) Polychaetous annelids from the coast of Paraíba state, Brazil. Revista Nordestina de Biologia, 21: 3-44.

Dunlop J.A. \& Arango C.P. (2005) Pycnogonid affinities: a review. Journal of Zoological Systematics and Evolutionary Research, 43(1): 8-21.

Feliciano M.L.M. \& Melo R.B. (2003) Atlas do Estado da Paraíba - Informação para gestão de Patrimônio Natural. João Pessoa: SEPLAN/IDENE. 58 p.

Hedgpeth J.W. (1943) Pycnogonida from the West Indies and South America collected by the Atlantis and earlier expeditions. Proceedings of the New England Zoölogical Club, 22: 41-58.

King P.E. (1974) British sea spiders: Synopses of the British Fauna, $n^{0}$ 5. New York: The Linnean Society of London, Academic Press London and New York. 67 p.

Krøyer H. (1844) Bidrag til Kundskab om Pycnogoniderne eller Søspindlerne. Naturhistorisk tidsskrift, Kjobenhavn, 1(2): 90-139.

Lima S.F.B., Queiroz V., Bravo de Laguna I.H. \& Mioso R. (2014) New host for Dissodactylus crinitichelis (Decapoda, Pinnotheridae): First record of occurrence on Mellita quinquiesperforata (Echinodermata, Echinoidea) (Decapoda; Echinodermata). Spixiana, 37(1): $61-68$.

Lima S.F.B., Lucena R.A., Santos G.M., Souza J.W., Christoffersen M.L., Guimarães C.R. \& Oliveira G.S. (2017) Inventory of mollusks from the estuary of the Paraíba River in northeastern Brazil. Biota Neotropica, 17(1): 1-12 (e20160239). doi: 10.1590/1676-0611-BN-2016-0239

Lucena R.A. (2016) Levantamento taxonômico de Pycnogonida da região nordeste do Brasil. Dissertação de Mestrado, Programa de Pós-Graduação em Ciências Biológicas (Zoologia). Universidade Federal da Paraíba, João Pessoa, Paraíba.

Lucena R.A. \& Christoffersen M.L. (2016) Pycnogonida (Arthropoda) from the Abrolhos Archipelago, Brazil, including a new species of Callipallene Flynn, 1929. Marine Biodiversity: 1-8. doi:10.1007/s12526-016-0481-6 
Lucena R.A., Araújo J.P. \& Christoffersen M.L. (2015) A new species of Anoplodactylus (Pycnogonida: Phoxichilidiidae) from Brazil, with a case of gynandromorphism in Anolodactylus eroticus Stock, 1968. Zootaxa, 4000(4): 428-444.

Marcus E. (1940a) Os Pantopoda brasileiros e os demais sul-americanos. Boletim da Faculdade de Filosofia, Ciências e Letras, Universidade de São Paulo, 19(4): 3-179.

Marcus E. (1940b) Pallenopsis fluminensis (Kröyer) e as Pallenopsis sul-atlânticas restantes (Arthropoda, Pantopoda). Revista de Entomologia, 11(1-2): 180-199.

Marques A.C. \& Lamas C.J.E. (2006) Taxonomia zoológica no Brasil: Estado da arte, expectativas e sugestões de ações futuras. Papéis Avulsos de Zoologia, 46(13): 139-174.

Medeiros C.R., Hepp L.U., Patrício J. \& Molozzi J. (2016) Tropical estuarine macrobenthic communities are structured by turnover rather than nestedness. PLoS ONE, 11(9): e0161082. doi:10.1371/journal.pone.0161082

Melo G.A.S. \& Veloso V.G. (2005) The Brachyura (Crustacea, Decapoda) of the coast of the State of Paraíba Brazil, collected by Project Algas. Revista Brasileira de Zoologia, 22(3): 796-805.

Melo R.S., Crispim M.C., Lima E.R.V. \& Nishida A.K. (2006) Estimativa da capacidade de carga recreativa dos ambientes recifais da Praia do Seixas (Paraíba - Brasil). Turismo - Visão e Ação, 8(3): 411-422.

Senna A.R., Figueiró R., Andrade L.F., Sardella C.J.R., Guedes-Silva E., Souza-Filho J.F., Miranda G.S., Oliveira G.R., Ferreira R.L. \& Docile T.N. (2013) A Importância e os desafios para o conhecimento e a catalogação da biodiversidade no Brasil. Acta Scientiae \& Technicae, 1(1): 53-86.

Staples D.A. (2002) Pycnogonum (Pycnogonida: Pycnogonidae) from Australia with descriptions of two new species. Memoirs of the Museum of Victoria, 59(2): 541-553.

Stock J.H. (1966) Pycnogonida - Résultats scientifiques des campagnes de la "Calypso". Fascicule VII. Campagne de la Calypso au large des cotes atlantiques de l'Amerique du Sud (19611962). I. 4. Annales de l'Institut Océanographique, 44: 385-406.

Stock J.H. (1974) Pycnogonids from the continental shelf, slope and deep sea of the tropical Atlantic and East Pacific. Bulletin of Marine Science, 24: 957-1092.

Stock J.H. (1992) Pycnogonida from southern Brazil. Tijdschrift voor Entomologie, 135: 113-140.

Tiago C.G. \& Migotto A.E. (1999) Filo Cheliceriformes (p. 199-206). In: Migotto A.E. \& Tiago C.G. (Orgs). Biodiversidade do Estado de São Paulo, Brasil: síntese do conhecimento ao final do século XX. Volume 3: Invertebrados marinhos. São Paulo: FAPESP. 310 p.

Varoli F.M.F. (1996) Aspectos da distribuição de Pantopoda em Sargassum de Itanhaém e Ubatuba, São Paulo, Brasil. Revista Brasileira de Zoologia, 13(1): 39-45. 